\title{
Semantic Similarity Measures for the development of Thai Dialog System
}

\author{
Khukrit Osathanunkul, James O’Shea, Zuhair Bandar, and Keeley Crockett \\ Department of Computing and Mathematics, Manchester Metropolitan University, \\ Chester St., Manchester M1 5GD, United Kingdom \\ khukrit.osathanunkul@stu.mmu.ac.uk, \\ \{j.d.oshea, z.bandar, k.crockett\}@mmu.ac.uk
}

\begin{abstract}
Semantic similarity plays an important role in a number of applications including information extraction, information retrieval, document clustering and ontology learning. Most work has concentrated on English and other European languages. However, for the Thai language, there has been no research about word semantic similarity. This paper presents an experiment and benchmark data sets investigating the application of a WordNet-based machine measure to Thai similarity. Because there is no functioning Thai WordNet we also investigate the use of English WordNet with machine translation of Thai words.
\end{abstract}

Keywords: word-to-word similarity, word-to-word comparison, semantic similarity measures, Benchmark, Thai Dialog System.

\section{Introduction}

Conversational Agents (CAs) are applied in a broad range of areas including business [1], education [2] and entertainment [3]. CAs maybe used in unmanned call centres or as personal shopping or navigation assistants to reduced operating cost and provide 24/7 access for users. Most CAs use English, However some work has been in done Chinese [4] and Japanese [5]. Little or no work has been done in Thai.

The chief barrier to deploying CAs effectively in the real world is the labour cost of scripting and maintenance. Consequently, a new generation of Short Text Semantic Similarity-based agents is being introduced to overcome their problem.

Recently, a new generation of CAs has begun to emerge using Short Text Semantic Similarity measures to analyse user utterances [6]. The majority of these make use of word-to-word similarity measures based on WordNet [7]. Although work has begun on a Thai WordNet [8] it is not fully populated.

Therefore, this paper investigates the research question: Can a WordNet-based word similarity measure be developed for the Thai language by translating Thai words into English and using the English Language WordNet in a word similarity algorithm?

This work requires a Thai word similarity benchmark data set. The Thai language is the official language of Thailand, spoken by over 20 million people [9]. The Thai alphabet uses forty-four consonants and fifteen basic vowel characters to create a 
word. These are horizontally placed, left to right, with no intervening space. Vowels are written after, before, below, or, above the consonant they modify, although the consonant always sounds first when the syllable is spoken.

Judgments of semantic similarity are a matter of human intuition and there is no objective method of obtaining ground truth ratings for experimental data. However, a 65 word pair data set in English collected by Rubenstein and Goodenough [10] using questionnaire-based has produced repeatable results [11]

The rest of this paper is organized as follows: Section 2 describes how the word semantic similarity measure works; Section 3 describes the collection of a Thai word similarity benchmark data set from participants using a method based on [10]; Section 4 discusses human and machine similarity ratings and section 5 outlines directions for future work.

\section{The Semantic Similarity Method}

There are numerous approaches to word semantic similarity; including thesaurus based [12, 13], dictionary based [14], and WordNet based [15, 16]. All use a lexical resource such as a directed graph or network and their semantic similarity is measured from the particular graph or network. WordNet [7] was developed by Princeton University, and is a machine-readable lexical database which is organized by word senses. Words in WordNet can be broken down into: 'nouns', 'verbs', 'adjectives 'and 'adverbs' which are grouped into sets of synonyms. These synonyms are called 'synsets' and are connected by means of 'conceptual-semantic' and 'lexical' relations. Figure 2 is part of the hierarchy of WordNet.

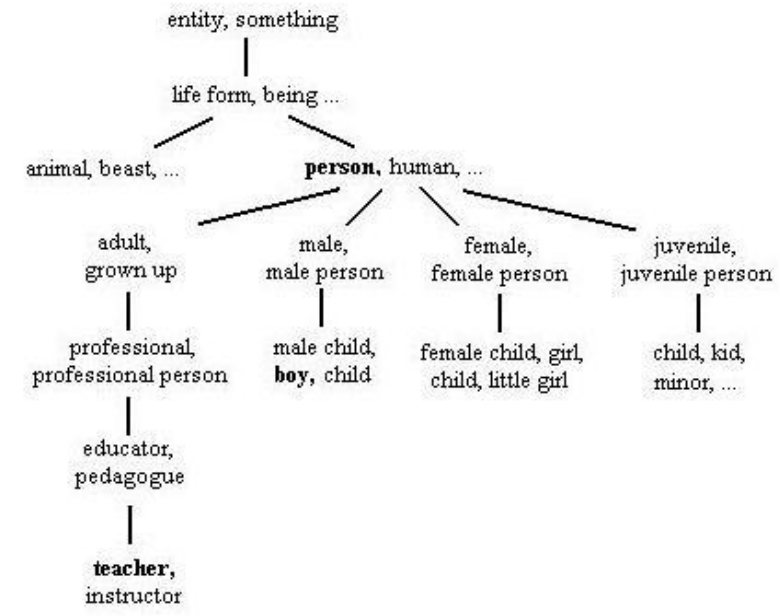

Fig. 1. Part of WordNet 
WordNet approaches can be classified as: information content methods [17, 18], edge counting methods [15, 19], feature based methods [20] and hybrid methods [21]; detailed reviews of word similarity can be found in [22], [23].

In this paper, we approximate the semantic similarity between two words by using the method shown in [22] that does the estimation by looking their subsumer of two words in WordNet. According to [24], [25] the STASIS measure performs very well when compared with other measures. Also, the STASIS measure is more effective when using it automatically as it is simple and fast to calculate. The STASIS measure calculates by the following formulas:

Given two words, $w 1$ and $w 2$, the semantic similarity $s(w 1, w 2)$ (equation 1$)$ can be calculate from:

$$
\mathrm{s}(\mathrm{w} 1, \mathrm{w} 2)=\tanh (0.45 * \mathrm{~h}) * \mathrm{e}^{\wedge}(-0.2 * \mathrm{~d})
$$

Where $d 1$ and $d 2$ are the depth of $w 1$ and $w 2$, and $h$ is the depth of their least common subsumer in WordNet, $d$ (equation 2) can be calculate from:

$$
d=d 1+d 2-(2 * h)
$$

For example, $w 1$ is teacher and $w 2$ is boy in Fig. 1, the depth of $w 1$ and $w 2$ are 7 and 5 respectively, the synset of person is called the subsumer for words of teacher and boy. Therefore, $h$ for teacher and boy is 3, and the $d$ of teacher and boy is 6 .

To address the research question in section 1 , the algorithm was adapted by using machine translation of Thai words to English before submitting them to the algorithm. This was done by choosing the first sense returned by the google translation [26] utility. The Google translation engine [27] uses the United Nations parallel corpus to train their translation engine. Apart from English to Thai, it can translate over 53 languages on which further research can be done.

\section{Experiment Procedures}

\subsection{Participants}

Similarity ratings were collected from 40 native Thai speakers to create a benchmark data set. The participants had an equal number of Art/Humanities and Science/Engineering backgrounds. They consisted of 12 undergraduates and 28 postgraduates studying in 4 different UK universities. The average age of the participants was 25 and standard deviation was 2.8, with 23 male and 17 female. This is comparable with participant groups used for English word similarity [10, 11] 


\subsection{Materials}

Following previous practice $[6,11]$ a representative subset of 30 word pairs was chosen from the Rubenstein and Goodenough data set. Those 30 word pairs were translated in to Thai by a native Thai speaker using the first meaning from an established Thai-English dictionary [28]. Each word pair was printed on a separate card using a standard Thai font. A questionnaire was produced containing instructions for recording similarity ratings and a small amount of personal data (Name, Confirmation of being a native Thai speaker, Age, Gender, and Academic background).

\subsection{Procedure}

The participants were asked to perform the following procedure:

1. Please sort the cards in to four groups in a rough order of the similarity of meaning of the word pair.

2. After sorting the cards into groups, order the cards in each group according to similarity of meaning. (i.e. the card that containing the lowest similarity of meaning is at the top of the group.)

3. Please recheck the cards in every group. You may change a pair of word to other groups at this stage.

4. Please rate the semantic similarity rating of each pair of words by writing a number between 0.0 (minimum similarity) and 0.9 for first group, 1.0 and 1.9 for second group, 2.0 to 2.9 for third group, 3.0 and 4.0 (maximum similarity) for fourth group on the recording sheet. You can use the first decimal place (e.g. 2.5) to show finer degrees of similarity. You also may assign the same value to more than one pair.

The cards were shuffled into a random order before being given to the participants.

\subsection{The Benchmark data sets}

The benchmark data set is shown in Table 1. R\&G words are the original words from Rubenstein and Goodenough [10]. Translated words are the Thai words translated as described in 3.2. 
Table 1. The average of similarity rating from 40 native Thai speakers.

\begin{tabular}{|c|c|c|c|c|c|}
\hline \multirow{3}{*}{$\begin{array}{l}\text { Pair } \\
\text { Number }\end{array}$} & \multicolumn{4}{|c|}{ Word Pair } & \multirow{3}{*}{$\begin{array}{l}\text { Human } \\
\text { Rating }\end{array}$} \\
\hline & \multicolumn{2}{|c|}{ Word 1} & \multicolumn{2}{|c|}{ Word 2} & \\
\hline & R\&G Word & Translated Word & R\&G Word & Translated Word & \\
\hline 1 & Cord & สายไฟ & Smile & รอยยิ้ม & 0.078 \\
\hline 5 & Autograph & ลายมือชื่อ & Shore & ชายฝั่ง & 0.022 \\
\hline 9 & Asylum & ที่หลบภัย & Fruit & ผลไม้ & 0.068 \\
\hline 13 & Boy & เด็กผู้ชาย & Rooster & นกตัวผู้ & 0.682 \\
\hline 17 & Coast & ฝั่งทะเล & Forest & ป่าไม้ & 0.632 \\
\hline 21 & Boy & เด็กผู้ชาย & Sage & นักปราชญ์ & 0.598 \\
\hline 25 & Forest & ป่าไม้ & Graveyard & สุสาน & 0.548 \\
\hline 29 & Bird & นก & Woodland & ป่าเขา & 0.595 \\
\hline 33 & Hill & เนินเขา & Woodland & ป่าเขา & 2.162 \\
\hline 37 & Magician & นักมายากล & Oracle & คำทำนาย & 1.260 \\
\hline 41 & Oracle & คำทำนาย & Sage & นักปราชญ์ & 1.298 \\
\hline 47 & Furnace & เตาหลอม & Stove & เตาไฟ & 1.612 \\
\hline 48 & Magician & นักมายากล & Wizard & พ่อมด & 1.570 \\
\hline 49 & Hill & เนินเขา & Mound & ภูเขา & 2.420 \\
\hline 50 & Cord & สายไฟ & String & เชือก & 0.882 \\
\hline 51 & Glass & แก้ว & Tumbler & ถ้วยแก้ว & 3.125 \\
\hline 52 & Grin & ยิ้มกว้าง & Smile & รอยยิ้ม & 2.330 \\
\hline 53 & Serf & ทาส & Slave & ข้ารับใช้ & 3.345 \\
\hline 54 & Journey & การเดินทาง & Voyage & การท่องเที่ยว & 2.788 \\
\hline 55 & Autograph & ลายมือชื่อ & Signature & ลายเซ็น & 3.223 \\
\hline 56 & Coast & ฝั่งทะเล & Shore & ชายฝั่ง & 3.218 \\
\hline 57 & Forest & ป่าไม้ & Woodland & ป่าเขา & 2.830 \\
\hline 58 & Implement & อุปกรณ์ & Tool & เครื่องมือ & 3.335 \\
\hline 59 & Cock & ไก่ตัวผู้ & Rooster & นกตัวผู้ & 1.515 \\
\hline 60 & Boy & เด็กผู้ช้าย & Lad & เด็กหนุ่ม & 2.425 \\
\hline 61 & Cushion & เบาะ & Pillow & หมอน & 2.035 \\
\hline 62 & Cemetery & ป่าช้า & Graveyard & สุสาน & 3.400 \\
\hline 63 & Automobile & รถยนต์ & Car & รถเก๋ง & 3.080 \\
\hline 64 & Midday & เที่ยงวัน & Noon & กลางวัน & 3.008 \\
\hline 65 & Gem & อัญมณี & Jewel & เพรชพลอย & 3.075 \\
\hline
\end{tabular}

\section{Experiment Results}

\subsection{Semantic Similarity Ratings}

Table 2 shows the semantic similarity ratings for the translated word pairs. Column 1 is the number of the word pair as shown in table 1 . Column 2 is the human rating for the Thai word pairs. Column 3 is the machine rating for the Thai word pairs using the algorithm described in section 2. Columns 4 and 5 are the human rating and the machine ratings obtain from Rubenstein and Goodenough [10]. Human ratings are 
calculated as the mean of the ratings provided by the set of participants for each word pair. All of the measures have been scaled in the range 0 to 1 to aid comparison.

Table 2. Semantic Similarity of Human Rating and Machine Rating.

\begin{tabular}{ccccc}
\hline \multirow{2}{*}{$\begin{array}{c}\text { Pair } \\
\text { Number }\end{array}$} & \multicolumn{2}{c}{ Thai } & \multicolumn{2}{c}{ English } \\
\cline { 2 - 5 } & Than Rating & $\begin{array}{c}\text { Thai } \\
\text { Machine Rating }\end{array}$ & $\begin{array}{c}\text { English } \\
\text { Human Rating }\end{array}$ & $\begin{array}{c}\text { English } \\
\text { Machine Rating }\end{array}$ \\
\hline 1 & 0.020 & 0.001 & 0.005 & 0.070 \\
5 & 0.006 & 0.038 & 0.015 & 0.050 \\
9 & 0.017 & 0.016 & 0.048 & 0.156 \\
13 & 0.170 & 0.241 & 0.110 & 0.107 \\
17 & 0.158 & 0.320 & 0.212 & 0.320 \\
21 & 0.150 & 0.366 & 0.240 & 0.366 \\
25 & 0.137 & 0.175 & 0.250 & 0.175 \\
29 & 0.149 & 0.200 & 0.310 & 0.200 \\
33 & 0.540 & 0.320 & 0.370 & 0.320 \\
37 & 0.315 & 0.016 & 0.455 & 0.245 \\
41 & 0.324 & 0.011 & 0.652 & 0.366 \\
47 & 0.403 & 0.448 & 0.778 & 0.548 \\
48 & 0.392 & 0.367 & 0.802 & 0.366 \\
49 & 0.605 & 0.655 & 0.822 & 0.817 \\
50 & 0.220 & 0.241 & 0.852 & 0.814 \\
51 & 0.781 & 0.817 & 0.862 & 0.817 \\
52 & 0.582 & 0.667 & 0.865 & 0.667 \\
53 & 0.836 & 0.670 & 0.865 & 0.818 \\
54 & 0.697 & 1.000 & 0.895 & 0.547 \\
55 & 0.806 & 1.000 & 0.898 & 0.818 \\
56 & 0.804 & 1.000 & 0.900 & 0.817 \\
57 & 0.708 & 1.000 & 0.912 & 1.000 \\
58 & 0.834 & 0.547 & 0.915 & 0.817 \\
59 & 0.379 & 0.448 & 0.920 & 1.000 \\
60 & 0.606 & 0.670 & 0.955 & 0.670 \\
61 & 0.509 & 0.547 & 0.960 & 0.817 \\
62 & 0.850 & 1.000 & 0.970 & 1.000 \\
63 & 0.770 & 1.000 & 0.980 & 1.000 \\
64 & 0.752 & 1.000 & 0.985 & 1.000 \\
65 & 0.769 & 1.000 & 0.985 & 1.000 \\
\hline & & & &
\end{tabular}

\subsection{Discussion}

The experimental results in the previous section suggest that the Thai word-to-word semantic similarity measure and semantic similarity of human rating provides good results. As can be seen in Figure 2, most of the correlation points are near the linear line with a correlation of 0.889 . 


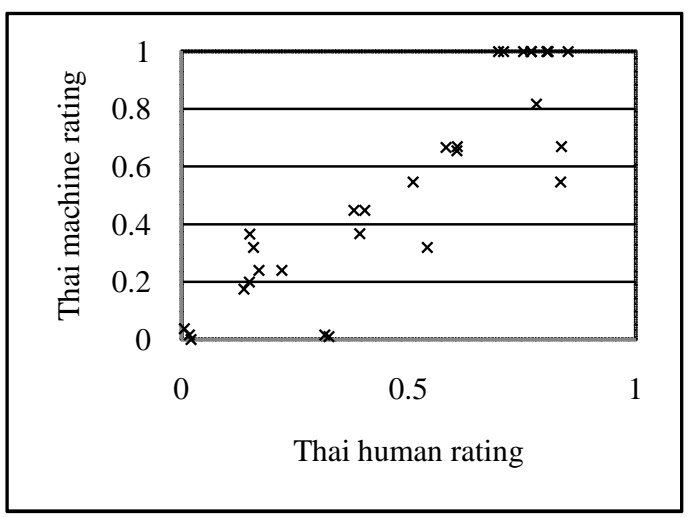

Fig. 2. The correlation between Thai human rating and Thai machine rating.

Table 3 illustrates the agreement of both of the machine measures with human ratings by calculating the correlation coefficients $(r)$ between the human ratings and the machine ratings over the data set.

Table 3. Correlation coefficients.

\begin{tabular}{ll}
\hline & Correlation $r$ \\
\hline Thai human similarity rating and machine similarity measure & 0.889 \\
English human similarity rating and machine similarity measure & 0.911 \\
\hline Thai human similarity rating and English human similarity rating & \multirow{2}{*}{0.857} \\
\hline Worst Thai native speaker participant and the least of the group & 0.639 \\
Best Thai native speaker participant and the least of the group & 0.946 \\
\hline
\end{tabular}

The Thai machine measure is performing close to the English machine measure, with a different of 0.022 between the two correlation coefficients. The Thai machine measure is also performing better than the correlation between the worst performing human and the least of the group $(r=0.639)$ which supports the view that it could form the basis of an effective algorithm. Furthermore, because the best performing human achieved the correlation of 0.946 it shows this benchmark data set is capable of measuring considerable improvement over the current algorithm and should be useful to researchers on Thai semantic similarity.

Word pair 37 (Magician-Oracle) and 41 (Oracle-Sage) in Table 2 illustrate an interesting problem. Both pairs of nouns contain the word 'oracle'. In general, 'Oracle' means either 'a message given by an oracle' or 'someone who gave advice to people or told them what would happen'; the definition can be found in [29]. We took the first meaning from Thai-English dictionary [28] which is 'คำทำนาย' likely to mean 'prediction'. After we translated the word back to English via google translate, the first meaning from google translation was chosen which is 'prophecy'. Consequently, the machine rating that we got is low because their subsume is entity. 
The human rating was significantly higher than the machine rating as shown in table 2. This shows that the way that the machines calculate the rating for pairs of nouns is based on only this first meaning that comes up in the dictionary. On the other hand, participants reported selecting a word sense based on all of their personal knowledge of a word. The measure cannot predict which sense a human will use. Table 4 illustrates the words found to raise problems of ambiguity during machine translation.

Table 4. The exception of translate word

\begin{tabular}{llllll}
\hline R\&G word & Thai word & Google word & R\&G word & Thai word & Google word \\
\hline Cord & สายไฟ & Wire & Voyage & การท่องเที่ยว & Travel \\
String & เชือก & Rope & Shore & ชายฝั่ง & Coast \\
Sage & นักปราชญ์ & Savant & Autograph & ลายมือชื่อ & Signature \\
Oracle & คำทำนาย & Prophecy & Jewel & เพรชพลอย & Gem \\
Cushion & เบาะ & Pad & Stove & เตาไฟ & Fireplace \\
Rooster & นกตัวผู้ & Bird & Wizard & พ่อมด & Necromancer \\
Woodland & ป่าเขา & Forest & Implement & อุปกรณ์ & Equipment \\
Serf & ทาส & Thrall & Asylum & ที่หลบภัย & Shadow \\
Automobile & รถยนต์ & Car & Mound & ภูเขา & Mountain \\
Journey & การเดินทาง & Travel & & & \\
\hline
\end{tabular}

However, the result of this research is encouraging, and indicates the potential of semantic similarity measurement for Thai words as we explained earlier.

\section{Future Work}

The long term goal of the current work is to apply a word similarity measure as a component of Short Text Semantic Similarity measurement $[19,30]$ that can be used in Thai CAs.

We described how the Thai word-to-word semantic similarity works, showed a Thai benchmark data set, and discussed the experimental results. We are in the early stage of a completely new design to develop the Thai CAs mentioned in section 4 . Further research will involve the development of the Short Text Semantic Similarity Measure for the development of a Thai dialog system. After we implement all the measures that we need to, we will develop a novel Thai CAs by using those measures. 


\section{References}

1. Lemon, O., Liu, X.: DUDE: a dialogue and understanding development environment, mapping business process models to information state update dialogue systems. EACL '06 Proceedings of the Eleventh Conference of the European Chapter of the Association for Computational Linguistics, Stroudsburg, PA, USA (2006)

2. Kopp, S., Gesellensetter, L., Kramer, N.C., Wachsmuth I.: A Conversational Agent as Museum Guide - Design and Evaluation of a Real-World Application. IVA 2005, LNAI 3661, pp. 329--343 (2005)

3. Ibarhim, A., Johasson, P.: Multimodal Dialogue Systems for Interactive TVApplications. ICMI '02 Proceedings of the 4th IEEE International Conference on Multimodal Interfaces, Washington DC, (2002)

4. Huang, F., et al: Language understanding component for Chinese dialogue system. International Conference on Spoken Language Processing, pp. 1053--1056, Oct. 16-20, Beijing (2000)

5. Ehsani, F., Bernstein, J., Najmi A.: An interactive dialog system for learning Japanese. Elsevier Science B.V. (2000)

6. O'Shea, J., Bandar, Z., Crockett, K. \& McLean, D.: A Comparative Study of Two Short Text Semantic Similarity Measures. KES-AMSTA 2008: p. 82--91 (2008)

7. Miller, G.A.: WordNet: A Lexical Database for English. Comm.Acm, vol.38, no.11, pages 39--41 (1995)

8. Sornlertlamvanich, V., et al: Review on Development of Asian WordNet. Japlo 2009 year book, pp. 276--285, (2009)

9. Lewis, M. P. (ed.): Ethnologue: Languages of the World, Sixteenth edition. Dallas, Tex.: SIL International. (2009)

10. Rubenstein, H. \& Goodenough, J. B.: Contextual Correlates of Synonymy. Communication of the ACM, vol. 8, No. 10, pp. 627--633 (1965)

11. Miller, G.A. and Charles, W.G.: Contextual Correlates of Semantic Similarity. Language and Cognitive Processes, vol. 6, No. 1, pp. 1--28 (1991)

12. Jarmasz, M., Szpakowicz, S.: Roget's Thesaurus and semantic similarity. In Proceedings of the International Conference on Recent Advances in Natural Language Processing. Borovetz, Bulgaria, pp. 212--219 (2003)

13. Morris, J., Hirst, J.: Lexical cohesion computed by thesaural relations as an indicator of the structure of text. Computational Linguistics, 17(1), 21--48 (1991)

14. Kozima, H., Furugori, T.: Similarity between word computed by spreading activation on an English dictionary. In Proceedings of $6^{\text {th }}$ Conference of the European Chapter of the Association for Computational Linguistics, pages 232--239, Utrecht (1993)

15. Rada, R., Mili, H., Bicknell, E., Blettner, M.: Development and application of a metric on semantic nets. IEEE transactions on systems, man and cybernetics, 19(1), pp. 17--30 (1989)

16. Wu, Z., Palmer, M.: Verb semantic and lexical selection. In: Proceedings of the $32^{\text {nd }}$ annual meeting of the association for computational linguistics, Las Cruces, NM, pp. 133$-8(1994)$

17. Resnik, P.: Using information content to evaluate semantic similarity in a taxonomy. In Proceedings of the $14^{\text {th }}$ international joint conference on artificial intelligence, Montreal, Canada, pp. 448--453, (1995)

18. Lin, D.: An information-theoretic definition of similarity. In Proceeding of the 15th International Conference on Machine Learning, pages 296-304 (1998)

19. Landauer, T.K., Foltz, P.W., Laham, D.: Introduction to Latent Semantic Analysis. Discourse Processes 25, 259--284 (1998)

20. Tversky, A.: Features of Similarity.: Psychological Review, 84(4), 327--352 (1977) 
21. Rodriguez, M. and Egenhofer, M.: Determining Semantic Similarity Among Entity Classes from Different Ontologies. IEEE Trans. On Knowledge and Data Engineering, 15(2), 442--456 (2003)

22. Li, Y., Bandar, Z. \& McLean, D.: An Approach for Measuring Semantic Similarity between Words Using Multiple Information Sources. IEEE Transactions on Knowledge and Data Engineering, vol. 15, no. 4, pp. 871-882 (2003)

23. Pedersen, T., et al.: Measures of semantic similarity and relatedness in the Biomedical domain, Journal of Biomedical Informatics 40, pp. 288--299 (2007)

24. Pirro, G.: A semantic similarity metric combining features and intrinsic information content, Data \& Knowledge Engineering, vol. 68, pp. 1289--1308 (2009)

25. Hliaoutakis, A., Varelas, G., Voutsakis, E., Petrakis, E.G.M., Milios, E.: Information retrieval by semantic similarity. Int'l Journal on Semantic Web \& Information Systems, 2(3), pp. 55--73 (2006)

26. Google translate.: (cited 08/10/2010) http://translate.google.com

27. Och, F. J.: Statistical Machine Translation: Foundations and Recent Advances. Tutorial at MT Summit 2005, Phuket, Thailand, (2005)

28. Trakultaweekoon, K., Porkaew, P., Supnithi, T.: LEXiTRON Vocabulary Suggestion System with Recommendation and Vote Mechanism. Proceedings of conference of SNLP- 2007, Thailand, (2007)

29. Longman: Longman Dictionary of Contemporary English (5th Edition). Longman, London, UK, (2009)

30. Li, Y., et al.: Sentence Similarity Based on Semantic Nets and Corpus Statistics. IEEE Transactions on Knowledge and Data Engineering, vol. 18, no.8, pp. 1138--1150 (2006) 